\title{
Physico- Chemical characteristics of compost (Cotonou, Benin, West Africa)
}

\section{${ }^{* 1}$ TCHAKPA CYRILLE; EDORH A.PATRICK; TOMETIN AS LYDE; DAOUDA MAMA; MICHEL BOKO}

\author{
'Laboratoire Pierre Pagney Climat, Eau, Ecosystème et Développement (LACEEDE) Université d'Abomey-Calavi, République du Benin \\ ${ }^{2}$ Biochemistry and Cellular Biology, University of Abomey-Calavi (UAC), O1BP 526 Cotonou, Benin \\ ${ }^{3}$ Laboratoire de Chimie Inorganique et de l'Environnement (LACIE), Département de Chimie, Faculté des Sciences et Techniques, \\ Université d'Abomey-Calavi 01 BP 4521 Cotonou, République du Bénin.
}

KEYWORDS: Cotonou, biodegradable waste, compost, physico- chemical characteristics, poor soil

\begin{abstract}
This work was led the town of Cotonou in Benin and particularly on the vegetable garden site of Houéyiho. It involved the valorization of the waste of this site by proceeding the aerobic composting of the biodegradable fraction of municipal solid waste collected in the markets. This consists among other rotten fruits of various plant debris and garbage obtained by initial sorting. After three months of biological decomposition, $48,531.78 \mathrm{~kg}$ of biodegradable waste was composted with a yield of 40,443.33 $\mathrm{kg}$ of fresh compost or approximately $83.33 \%$ compost. The moisture content of the biodegradable fraction is $65 \%$. The physico-chemical characteristics of compost produced are as follow: $12.7594 \pm 0.1006 \mathrm{mg} / \mathrm{kg}$ of heavy metals, the $\mathrm{C} / \mathrm{N}$ ratio is $13 \%$ and the rate of total phosphorus is $0.34 \%$ and $61.18 \mathrm{meq} / 100 \mathrm{~g}$ of Dry Weight exchangeable bases. The humus of our compost has a high capacity of cationic exchange (CCE) and fixed mineral nutrient ions such as $\mathrm{K}^{+}$and $\mathrm{Ca}^{2+}$ and phosphate in order to make them available for plant growth and development and proving the poverty of the soil of this site and their increased need of organic amendment. $\odot$ JASEM
\end{abstract}

\section{http://dx.doi.org/10.4314/jasem.v18 i2.22}

Introduction: During the last decade, African towns are facing a serious urban development problem due the increasing in his population over the last two decades. This strong population growth is accompanied by a significant production of garbage disposal which become a concerns for municipalities (In info CREPA, 1995)

In the town of Cotonou, the economical capital of Benin, $40 \%$ of waste is collected and disposed of by approved structures (DST / Mayor of Cotonou, 2007) without any form of treatment. The excess nonevacuated and estimated at $60 \%$ per day, affects life quality of inhabitants of Cotonou which also have a particularly unhealthy lifestyle. Another observation is that some people live with their waste. Cotonou Neighborhoods are the evidence with the presence of large piles of garbage in the empty spaces and streets side. These garbage dumps are also causing visual pollution, the proliferation of diseases vectors, air pollution due to the noxious greenhouse gases gas emissions such as (methane, $\mathrm{CO} 2$ ). The situation is particularly of the concern because these wild dumps are located, in swamps and serve lavatories riparian populations. These marshes which were natural runoff receptacles are subject to rapid filling whose consequences are manifested by floods in the rainy season. This causes difficulties in urban management and environmental pollution. So to overcome the problems of waste management in urban meddle, treatment by composting has been found to be a way for recycling and reused the later. The obtained compost has been summit to physic-chemical parameters analysis in order to assess its quality and the possibility to be used as fertilizer for soil amendment. Parameters such as dry matter, moisture, mineral matter, organic matter, total organic carbon, inorganic carbon, iron, total nitrogen , $\mathrm{N} / \mathrm{C}$ ratio , total phosphorus, nitrate, $\mathrm{pH}_{\text {water }}, \mathrm{pH}_{\mathrm{KCl}}$, exchangeable basis, CEC, size and heavy metals (lead) were measured.

\section{MATERIALS AND METHODS}

Study area: The market gardening site is situated between $6^{\circ} 21^{\prime} 39^{\prime}$ ' and 6 $6^{\circ} 22^{\prime} 01$ " Northern latitude and between $2^{\circ} 23^{\prime} 45^{\prime \prime}$ and $2^{\circ} 24^{\prime} 08^{\prime \prime}$ longitude. Its surface extends approximately on 16 ha for a population of 354 market-gardeners.

Methods: For most of analyzes, AFNOR standards on "Soil Quality" were used (Mathieu et al, 2003; AFNOR, 2004). The similarities in composition and physico-chemical characteristics between soils and sediments have motivated the use of these standards. The main materials used are shown in Table 2.

Samples Preparation: Samples were subjected different treatments according to the NF X31 -101 standard include drying at ambient (about $40^{\circ} \mathrm{C}$ ), the scalping, the sieving using a sieve size of $2 \mathrm{~mm}$ in diameter and obtained samples were put inside 
plastics in PPTF (Mathieu et al, 2003. AFNOR, 2004).

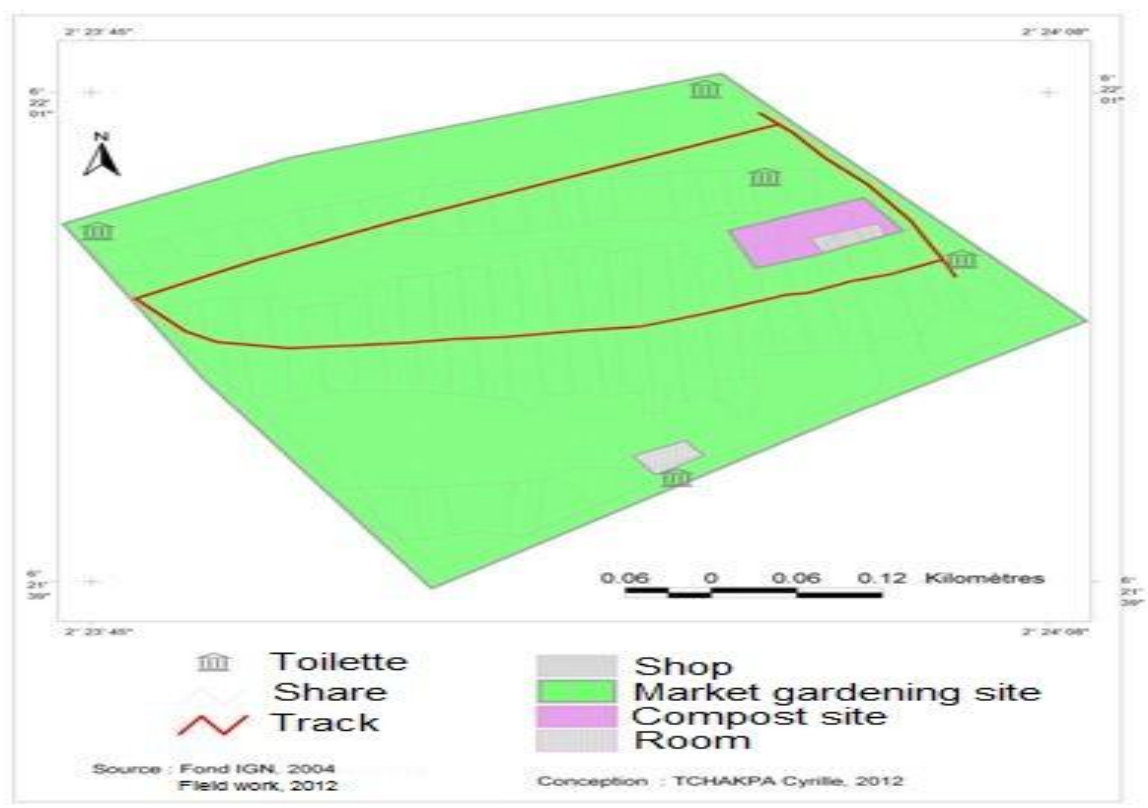

Fig1: localization of the study area

Physico-chemical characterization of sediments: The residual moisture content ( standard NF X31-102 ) was determined by mass difference of $10.0 \mathrm{~g}$ of the sediment after drying at $103 \pm 2{ }^{\circ} \mathrm{C}$ until the weight is constant in an oven ( Guevara - Riba et al., 2004; Cappuyns 2004; AFNOR, 2004). The $\mathrm{pH}$ of the sediment was measured on sediment supernatant by a $\mathrm{pH}$ monitoring after $60 \mathrm{~min}$ of stirring $2 \mathrm{~h}$ then test. The sediment / water ratio was $2 / 5(\mathrm{w} / \mathrm{v})$. This principe and methodology of this method are described in the NF X 31-103 standard. The electric conductivity was also determined on the supernatant, sediment/water in a ratio of $1 / 5(\mathrm{w} / \mathrm{v})$ after $1 \mathrm{~h}$ of stirring and filtration on Whatman paper at 0.45 microns. Carbonates were determined following the Rauret (1988) protocol by assay for acid-base return $5.0 \mathrm{~g}$ of finely ground dry sediment. Inorganic carbon is the fifth of the rate of carbonate. Total organic matter was determined by loss of weight method by ignition at $450^{\circ} \mathrm{C}$ for $3 \mathrm{~h}$ of $0.5 \mathrm{~g}$ of sediment (Mathieu et al, 2003. AFNOR, 2004). For the determination of organic carbon, we have used the inverse relationship of Walkley -Black organic carbon which corresponds to $58 \%$ of the rate of organic matter. Total carbon is then equal to the sum of organic carbon and inorganic carbon. The assay Atomic Absorption Spectrophotometer (AAS) Perkin-Elmer, model 2380, with flame air / acetylene iron $(\mathrm{Fe})$, manganese $(\mathrm{Mn})$, phosphorus $(\mathrm{P})$, and lead $(\mathrm{Pb})$ was performed on $0.25 \mathrm{~g}$ of finely ground of sediment by the method of mixture of perchloric acid and hydrofluoric ( Baize 2002; Pagnanellia et al., 2003. ). NF X 31-151 was used to describe the dissolution of metallic trace elements by etching with hydrochloric and nitric acids (commonly called aqua regia method) or by etching with hydrofluoric acid.
These methods lead to obtaining a solution for assays absorption or atomic emission spectrometry.

The first method, that of aqua regia, which consist on the dissolution of the sample in a mixture of hydrochloric and nitric acid by boiling under reflux. The disadvantage is that it does not allow the dissolution of metals bound to the silicate structure. In which concern hydrofluoric acid method allows to dissolve the silicate compounds but requires a preliminary calcination at $450^{\circ} \mathrm{C}$ (to destroy the organic matter), followed by dissolution in concentrated hydrofluoric acid in the presence of perchloric acid. After removal of hydrofluoric and perchloric acid by evaporation, the residue is attacked by hydrochloric and nitric acids. The disadvantage of this method is the possible loss of volatile components in the form of compounds such as tetraethyl lead or mercury during calcinations and evaporation of silica in the form of SiF4. The method that was chosen for this study is that of hydrofluoric acid as the disadvantages of this method does not impact much the targeted parameters. $0.25 \mathrm{~g}$ of the sample prepared for test is weighed into a quartz capsule, it is placed in an oven (furnace) and then calcinated at $450^{\circ} \mathrm{C}$ for 3 hours, the capsule was removed and cooling.

The solid residue is then transferred to a PTFE cap then added $5 \mathrm{ml}$ of hydrofluoric acid (48\%) and 1.5 $\mathrm{ml}$ of perchloric acid $(70 \%)$ then heated on a hot plate and allowed to evaporate to dryness.

Always on the heating system, it was added $3.75 \mathrm{ml}$ of hydrochloric acid (38\%) and $1.25 \mathrm{ml}$ of nitric acid (65\%), once the finished dissolution, the solution 
was poured into a volumetric flask of $100 \mathrm{ml}$, complete to volume with demonized water and analyzed for SAA (Atomic Absorption Spectrometer). The device that was used to measure the concentrations of various elements was a ULTIMA 2 Jobin Yvon HORIBA.

Sequential extraction: We applied the sequential extraction procedure for the speciation of iron and manganese.

To perform the sequential extraction, the method we used was the one of Tessier et al (Tessier 1979). It's based on the use of a series of more or less selective reagents chosen to solubilized various mineralogical fractions successively. Solubilization of these fractions results in the release of metals bonded by their different mechanisms: ion exchange, adsorption, co-precipitation, complexation etc.
To perform the experiments, $1 \mathrm{~g}$ of sample was weighed into a polyethylene centrifuge tube of $40 \mathrm{ml}$ on which the sequential extraction protocol described in Table III.2 was applied. The cfifth fraction was not experimentally determined, it was calculated by difference between the total concentration of components (after complete mineralization), and the sum of the four fractions. Between two successive stages of extraction, the sediment was centrifuged for $15 \mathrm{~min}$ at $4500 \mathrm{rpm}$. The supernatant is then filtered (filter paper 0.45 microns), acidified with a few drops of nitric acid, then made up to $25 \mathrm{ml}$ with deionized water and analyzed immediately. The solid residue was used for the following step after washing with dematerialized water $(10 \mathrm{ml})$, filtration and centrifugation.

Table 1: sequential extraction procedure of iron and manganese for 5.0g of sample

\begin{tabular}{|c|c|c|c|}
\hline Fractions & Extraction Reagents & Volume (ml) & $\begin{array}{c}\text { Time } \\
\text { (h) }\end{array}$ \\
\hline Exchangeable & $1 \mathrm{M} \mathrm{MgCl} 2, \mathrm{pH} 7,20^{\circ} \mathrm{C}$, agitation continue & 8 & 2 \\
\hline $\begin{array}{l}\text { Acido-soluble, bind to } \\
\qquad\left(\mathrm{CO}_{3}{ }^{2-}\right)\end{array}$ & $1 \mathrm{M} \mathrm{CH} 3 \mathrm{COONa} / \mathrm{CH} 3 \mathrm{COOH}, \mathrm{pH} 5,20^{\circ} \mathrm{C}$, continuelle agitation & 8 & 24 \\
\hline Reducible & $0,04 \mathrm{M} \mathrm{NH} 2 \mathrm{OH}, \mathrm{HCl}+25 \% \mathrm{CH} 3 \mathrm{COOH}, 95^{\circ} \mathrm{C}$ agitation intermittente & 20 & 24 \\
\hline Oxydizible (O. M) & $\begin{array}{c}30 \% \mathrm{H} 2 \mathrm{O} 2,0,02 \mathrm{M} \mathrm{HNO} 3, \mathrm{pH} 2 ; 85^{\circ} \mathrm{C}, \\
\text { Intermittente agitation } ; 3,2 \mathrm{M} \mathrm{CH} 3 \mathrm{COONH} 4,+ \\
20 \% \mathrm{HNO} 3\end{array}$ & $\begin{array}{l}5 \\
3 \\
5\end{array}$ & 10 \\
\hline Residuelle & $40 \% \mathrm{HF}+60 \% \mathrm{HClO}_{4}$ (Total Mineralization) & 5 & Dry \\
\hline content & $40 \% \mathrm{HF}+60 \% \mathrm{HClO}_{4}$ (Total Mineralization) & 10 & Dry \\
\hline
\end{tabular}

\section{RESULTS AND DISCUSSIONS}

Table 2: Results of physico-chemical analysis of compost produced

\begin{tabular}{|c|c|c|c|c|}
\hline \multirow{2}{*}{$\begin{array}{c}\text { Para meters } \\
\text { Dry Matter } \\
\text { Moisture content }\end{array}$} & \multirow{2}{*}{$\frac{\text { Units }}{51 \%}$} & Normes & Materials & Methods \\
\hline & & & Cuve, fournace, micro & METSON \\
\hline $\begin{array}{c}\text { Organiic Matter content } \\
\text { Organic Matter (OM) }\end{array}$ & $27.62 \%$ & to 20 & & Ignition \\
\hline \multirow{2}{*}{$\begin{array}{l}\text { Total organic Carbon } \\
\text { Total nitrgen }\end{array}$} & $14,97 \%$ & & Spectro A A and reagents & \\
\hline & $1,15 \%$ & & & Walkley Black \\
\hline & $13 \%$ & 10 & & \\
\hline \multirow{2}{*}{\multicolumn{5}{|c|}{$\begin{array}{l}\text { pHWater } \\
\text { pHKCl }\end{array}$}} \\
\hline & & & & \\
\hline \multirow{2}{*}{$\begin{array}{l}\text { Manganese } \\
\text { Iron }\end{array}$} & 291,667 ppm & & Spectrophotometer & \\
\hline & $10965,389 \mathrm{ppm}$ & & Spectrophotometer & \\
\hline Sodium & 2,11Méq/100g Dry & & & \\
\hline exchan & Weight (DW) & & Flamm Spectrophotometer & \\
\hline Potassium & $9,51 \mathrm{Meq} / 100 \mathrm{~g} \mathrm{DW}$ & & & \\
\hline \multirow{4}{*}{$\begin{array}{l}\text { Calcium } \\
\text { Magnesium } \\
\text { Summ B. E } \\
\text { CEC }\end{array}$} & $14,28 \mathrm{Meq} / 100 \mathrm{~g}$ DW & & & \\
\hline & $>2000 \mu \mathrm{m}$ (refusal) 17,52 & & & \\
\hline & $2000-200 \mu \mathrm{m}$ (coarse & & & \\
\hline & 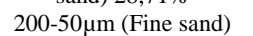 & & & \\
\hline \multirow[t]{5}{*}{ Granulometry } & $50-20 \mu \mathrm{m}$ (coarse silt) & & & \\
\hline & $14,49 \%$ & & PIPETTE de ROBINSON & \\
\hline & $20-2 \mu \mathrm{m}$ (Fine silt) & & & METSON \\
\hline & $11,18 \%$ & & & \\
\hline & $2-0 \mu \mathrm{m}$ (clay) $10,1 \%$ & & & \\
\hline Texture & coarse & & & \\
\hline Heavy metal (lead) & $12.7594 \pm 0.1006 \mathrm{mg} / \mathrm{Kg}$ & & $\begin{array}{l}\text { Mill, balance, oven, SAA1 } 10 \\
\text { glassware, lamp and reagents }\end{array}$ & METSON \\
\hline
\end{tabular}


Source: Analysis in the Laboratory of Inorganic Chemistry and the Environment (LACIE) FAST and in the Laboratory of soil, water and environment sciences (INRAB)

The compost $\mathbf{p H}$ is slightly acidic. This acidity can be attributed to low levels of carbonates.

Conductivity: The average of the measurements presented shows a higher rate of soluble salts in the compost.
The analyzed compost has high content of organic matter. It is important to notice that the mass loss during drying at $103^{\circ} \mathrm{C}$ is not only the loss of water; it may also correspond to the evaporation of volatile organic material likely to occur from $60^{\circ} \mathrm{C}$. There is also high values of exchangeable bases $(\mathrm{Ca}=14.28$, $\mathrm{Mg}=17.32, \mathrm{~K}=9.51, \mathrm{Na}=2.11)$ and cationic exchange capacity

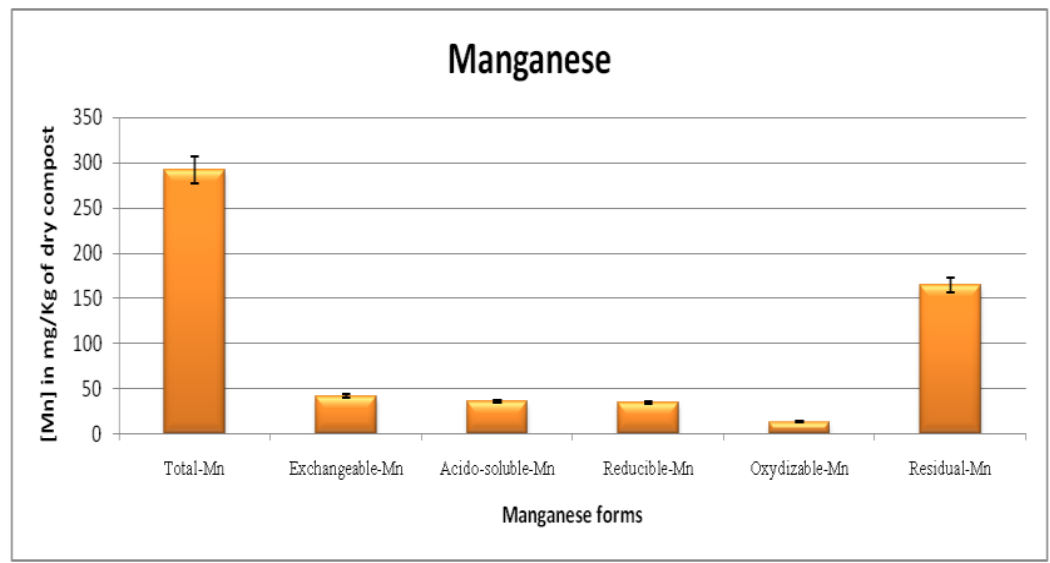

Fig 1

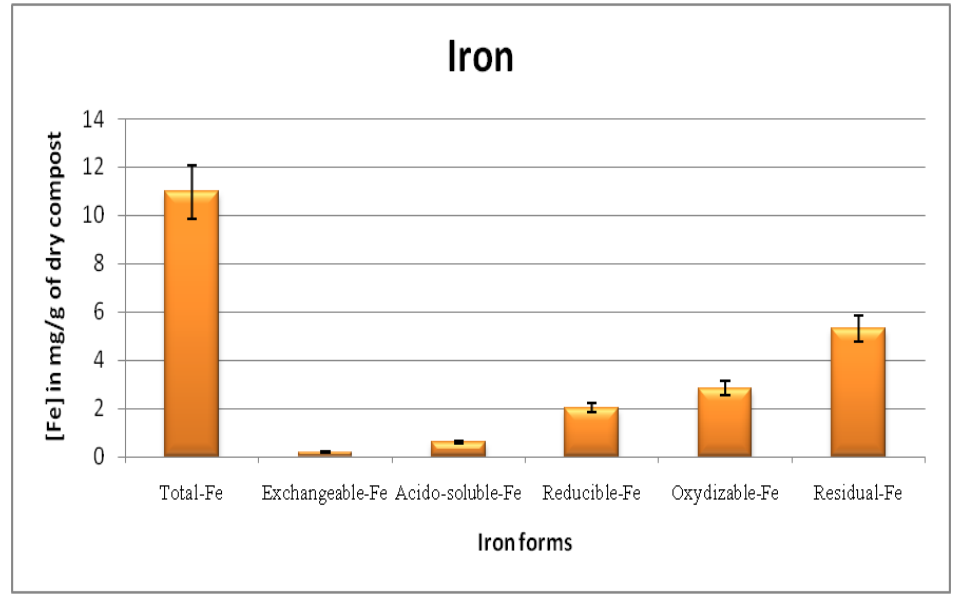

Fig 2

Tables 3: Results of the sequential extraction.

\begin{tabular}{lrr}
\hline & \multicolumn{2}{c}{ Percentage (\%) } \\
Element form & Iron & Manganese \\
\hline Exchangeable-form & 1,72 & 14,48 \\
Acido-soluble-form & 5,5 & 12,38 \\
Reducible-fom & 18,45 & 11,9 \\
Oxydizable-form & 25,86 & 4,64 \\
Residual-form & 48,47 & 56,6 \\
Total & 100 & 100 \\
\hline
\end{tabular}

The exchangeable fraction of manganese immediately available to plants is very important compared to that of iron. This could come from the extensive use of detergents containing particularly manganese (potassium permanganate) for hygiene and dinner. Thus we can see that the major domestic effluents 
impacting on the physico-chemistry of our compost due to the very high value observed for conductivity. Compost is rich in iron. The largest fraction of the iron bound form of organic matter (more than the quarter of all the iron). The residual iron is less than $50 \%$ of the total iron bioavailability; therefore iron is strong to be available to plant growth. This shows the main component source compost.

The evaluation of the quality of compost is very complicated because the special needs of soils and plants in addition to the range of methods of using composts:

National Standard of Canada for organic amendments (1996) indicate that a mature compost must have a $\mathrm{C} / \mathrm{N}$ less than or equal to 25 since in general report, the decomposition of compost with a $\mathrm{C} / \mathrm{N}$ ratio lower or equal to 25 in a soil does not involve the immobilization of the nitrogen from the soil to the detriment of plant.

The maturity is often assessed by the $\mathrm{C} / \mathrm{N}$ ratio It has been showed that $\mathrm{C} / \mathrm{N}$ ratio close to $10-15$ corresponds to a mature compost can significantly improve soil on which plants derive nutrients for growth (Namkooing et al. , 1999).

In which concern the compost we produced, the $\mathrm{C} / \mathrm{N}$ ratio is 13 which is quite acceptable. Indicating that the compost was mature. This value is slightly higher than that found by GNONZA, (2003) which is 11.50. For Fair and Pommel (1987), a C/N ratio between 10 and 25 is a stabilizer for the soil on which the compost is applied. But this report alone is not sufficient to estimate the maturity of compost, it is necessary to combine it with other physico- chemical parameters.

Several authors such as HAMDA and Inoko (1980) cite a compost with CEC less than $60 \mathrm{meq} / 100 \mathrm{~g} \mathrm{DW}$ is mature. The compost produced in our tests slightly exceeded this criterion. The cation exchange capacity is the ability of an organic material to capture cations reversibly. Humus has a high CEC and fixed mineral nutrient ions such as $\mathrm{K}^{+}$and $\mathrm{Ca}^{2+}$ and phosphate in order to make them available to plants for their growth and development (Mustin, 1987). The CEC is a general index of the maturity of compost and its value tends to increase gradually during composting and capping.

The $\mathrm{pH}$ is also an indicator of compost maturity. Indeed, the mature compost has a $\mathrm{pH}$ between 7 and 9 (Avnimelech et al., 1996). The measured $\mathrm{pH}$ ranging from 6.5 to 7 are a little weak and would be due to the soil acidity in the city of Cotonou, where the experiment was carried out .

The particles whose size is less than $2 \mathrm{~mm}$ is the most important treatment whatever proportion. Compost has a structure in which the particles are smaller and relatively homogeneous, and the texture is close to that of a soil. This result confirms several other obtained by several authors such as Soudi (2001) and Charnay (2005).

The high rate of fines compost could be explained by the decomposition/degradation during composting and high levels for waste items. High proportions of fine particles show a good quality compost although refusals are around $17.52 \%$.

Evolution of organic carbon during composting: Organic carbon content was estimated according to the relationship (Walkley-Black) which estimates that the organic carbon to $58 \%$ of organic matter indicates that sediment retention are a potential source for the production of humic and fulvic acid. The average value is $14.278 \%$ greater than that found by Gnonzan, (2003). Indeed, various authors (Coquery 1995 Lin 1998) have linked the content of metal pollutants to organic carbon concentration, they reveal the affinity between heavy metals and organic carbon

Concerning lead the compost sample subjected to the test contain an average of $12.7594 \pm 0.1006 \mathrm{mg} / \mathrm{kg}$ of lead. Considering that the average levels of lead in agricultural soils range from 2 to $200 \mathrm{mg} / \mathrm{kg}$ of soil (Swaine, 1955) and the average content in contaminated soils is $17 \mathrm{mg} / \mathrm{kg}$ of lead (Nriagu, 1978), it appears that the analyzed compost contains a relatively high content of lead but within the allowable limits. Its use in the context of gardening or urban agriculture should be rational in order to prevent accumulation of this trace element in living organisms.

Conclusion: In sight of the obtained results of the physicochemical analyses the $\mathrm{pH}$ values show that the compost is basic and can easily balance acid grounds, its holding water capacity (49\%) is more or less strong. A report/ratio $\mathrm{C} / \mathrm{N}$ of 13 obtained is stabilizing for the grounds to which the compost is applied. The humus of our compost has a strong CEC and fixes the nutritive mineral ions such as the cations $\mathrm{K}^{+}$and $\mathrm{Ca}^{2+}$ and phosphates so as to make them available to the plants for their growth and their development. The compost is used then as support for the crop plants; it is an organics fertilizing.

According to these previews results, the studied compost could be reused in agriculture as soil amendment.

\section{REFERENCES}

Asecna, (2002). Rapport scientifique sur la variabilité du climat au Bénin, 11 p. 
Avnimelech, Y (1996). Stability indexes for municipal solid waste compost. Compost Science \& Utilization, page 26.

Crépa-Benin (1995). Élimination des déchets solides dans le quartier st Michel à Cotonou $5 \mathrm{p}$.

Direction des Services Techniques (2007). Synthèse sur la gestion des ordures ménagères. DST/ Mairie de Cotonou 17 p.

Gnonzan, P ; A (2003). Valorisation des ordures ménagères : influence du rapport des constituants de compost à base d'ordure sur la production du chou-pommé (Brassica oléracéa L.). Mémoire de fin de formation pour le diplôme d'ingénieur des travaux. (DIT), APE/CPU, 75 p.

Guevara-Riban, A; Sahuquillo, A; Rubio, R; Rauret, G (2004), Assessment of mobility in dredged harbour sediments from Barcelona, Spain. Science of the Total Environment, vol. 321, pp. 241-255.

Insae (2004). Cahier des villages et quartiers de ville. Département du littoral, Direction des Etudes Démographiques, Cotonou, Mai 2004, 22 p.

Juste, C ; Pommel, B (1977). La valorisation agricole des déchets. Article publié, Yaoundé, 9 p.

Kannikpo, C (2013). Apparillage et mode oppératoire du dosage des métaux par spectrophotométrie atomique; Laboratoire des Sciences du Sol, Eaux et Environnement (LSSEE/CRA Agonkanmey/INRAB); synthèse de documents de travail ; 3 p. version actualisée en 2013

Kounde, C ; Z (1998). Etude de l'impact du compost à base des ordures ménagères sur la fertilité d'un sol ferrugineux tropical à DJOUGOU. Thèse d'ingénieur soutenue en 1998, FSA, Science du sol, $88 \mathrm{p}$.
Mustin, M (1987). Le compost: gestion de la matière organique. Editions François DUBUSC 35, rue Mathurin Régnier 75015 paris, 960 pages.

Namkooing, W (1999). A comparative evaluation of maturity parameters for food waste composting. Compost Science of Utilization 7: 55-62.

Nriagu, J; O (1978). The biogeochemistry of Lead in the Environment. Part A. Ecological Cycles. Elsevier/ North-Holland, New York, In LAPERCHE et al. (2004)

Pagnanellia, F; Espositob, A; Toroa, L; Vegliob, F (2003). Metal speciation and $\mathrm{pH}$ effect on $\mathrm{Pb}$, $\mathrm{Cu}, \mathrm{Zn}$ and $\mathrm{Cd}$ biosorption onto Sphaerotilus natans: Langmuir-type empirical model. Water Research, 37: 627-633

Rauret, G; Rubio, R; Lopez-Sanchez, J; F and Casassas, E (1988). Determination and speciation of copper and lead in sediments of a Mediterranean river (River Tenes, Catalonia, Spain), Water Research 22, 449-455.

Swaine, D; J (1955). The trace element content of soils Techn. Common Wealth Bureau Soil Sci,York, England, Herald printing works, 157 p.

Soudi, B (2001). Compostage des déchets ménagers et valorisation du compost : cas des petites et moyennes communes au Maroc, édition Actes, $104 \mathrm{p}$.

Tessier, A; Campbell, P; G; C; et Bisson, M (1979). Sequential extraction procedure for the speciation of particulate trace metals. Anal. Chem., vol.51, pp 844-851. 